\title{
Myoglobin and Cytochrome Response during Repair of Iron Deficiency in the Rat*
}

\author{
Peter R. Dallman $\dagger$ and Herbert C. Schwartz $\ddagger$ \\ (From the Department of Pediatrics, Stanford University School of Medicine, \\ Palo Alto, Calif.)
}

Until recently, hemoglobin was believed to be the only heme protein affected by dietary iron deficiency (1). Several studies, however, have shown that myoglobin, the cytochromes, and catalase may be significantly reduced in concentration in experimental animals and in man (2-9). In the iron-deficient rat, the susceptibility to depletion of heme protein has been found to vary from tissue to tissue. Cytochrome c $(7,9)$ and myoglobin (9) can be decreased to less than half of control concentrations in skeletal muscle, which normally accounts for over $75 \%$ of the total body content of these heme proteins. A similarly marked decrease in concentration of cytochrome $c$ has been noted in intestinal mucosa (9). Other tissues such as brain, heart muscle, liver, and kidney are affected to a lesser degree or are entirely spared $(7,9)$. In the present investigation, the rate of repair of heme protein deficiency in the rat was studied in the most severely depleted tissues during the course of iron repletion.

\section{Methods}

Male rats of the Wistar strain were placed on a lowiron regimen as follows: Mothers with the 10-day-old males of their litters were provided a diet of dried whole milk ${ }^{1}$ supplemented with a vitamin and mineral formula (10) that contained no added iron. Distilled water was provided ad libitum. Control litters were provided with

\footnotetext{
* Submitted for publication April 20, 1965; accepted June 21, 1965.

These investigations were supported by U. S. Public Health Service research grant HE-07184 from the National Heart Institute and training grant 9 T1 HD-49 from the National Institute of Child Health and Human Development, and by a grant-in-aid from the John A. Hartford Foundation.

$\dagger$ Address requests for reprints to Dr. Peter R. Dallman, Dept. of Pediatrics, Stanford University School of Medicine, Palo Alto, Calif. 94304.

$\ddagger$ John and Mary R. Markle Scholar in Academic Medicine.

1 Borden Dryco.
}

$0.25 \mathrm{~g}$ of ferrous sulfate per $\mathrm{L}$ of drinking water. The rats were weaned at 21 days of age. After 36 and 56 days of age, groups of iron-deficient rats received ferrous sulfate at the same concentrations as those provided to control animals.

Animals were killed by decapitation at various intervals after initiation of the dietary regimen. Tissues were removed immediately and stored at $-20^{\circ} \mathrm{C}$. Cytochrome c (7) and myoglobin (11) are stable in frozen tissues and were assayed within 2 weeks. The quadratus lumborum muscle was used for the determination of skeletal muscle cytochrome c. Intestinal mucosa was obtained by scraping the entire small intestine with a spatula after gentle removal of bowel contents. Cleaning of the small intestine by saline washing resulted in similar concentrations of cytochrome $c$ per gram of dry tissue.

Dry weight was determined on samples of tissue by bringing specimens to constant weight in a drying oven at $120^{\circ} \mathrm{C}$. Since the water content of intestinal mucosa varied from animal to animal, concentrations of cytochrome $\mathrm{c}$ in this tissue are reported on the basis of dry weight. The water content of skeletal muscle remains relatively constant even with severe iron deficiency (7), and concentrations of heme protein in this tissue have been reported in terms of wet weight.

Venous hemoglobin was quantitated as cyanmethemoglobin (12). Myoglobin was determined in the muscles of the lower extremities by the method of Åkeson, Ehrenstein, Hevesy, and Theorell (13). In this method, myoglobin is measured spectrophotometrically after separation from other heme proteins by precipitation with ammonium sulfate and chromatography on carboxymethylcellulose. Cytochrome $c$ was determined by the method of Rosenthal and Drabkin (14) with minor modifications (9). Cytochrome c is measured spectrophotometrically after isolation from other heme proteins by ammonium sulfate and trichloroacetic acid precipitation. Cytochrome oxidase was histochemically localized in sections of the upper jejunum by the method of Burstone (15). Frozen sections $12 \mu$ thick were incubated for 30 minutes with $p$-aminodiphenylamine as substrate and 8-amino-1,2,3,4-tetrahydroquinoline as the coupler. $\mathrm{Hy}$ drolyzable iron in liver was determined colorimetrically with orthophenanthroline by the method of Kaldor (16).

The mean concentrations of hemoglobin, myoglobin, cytochrome c, and liver iron were calculated in each age group from individual determinations in five to seven ani- 


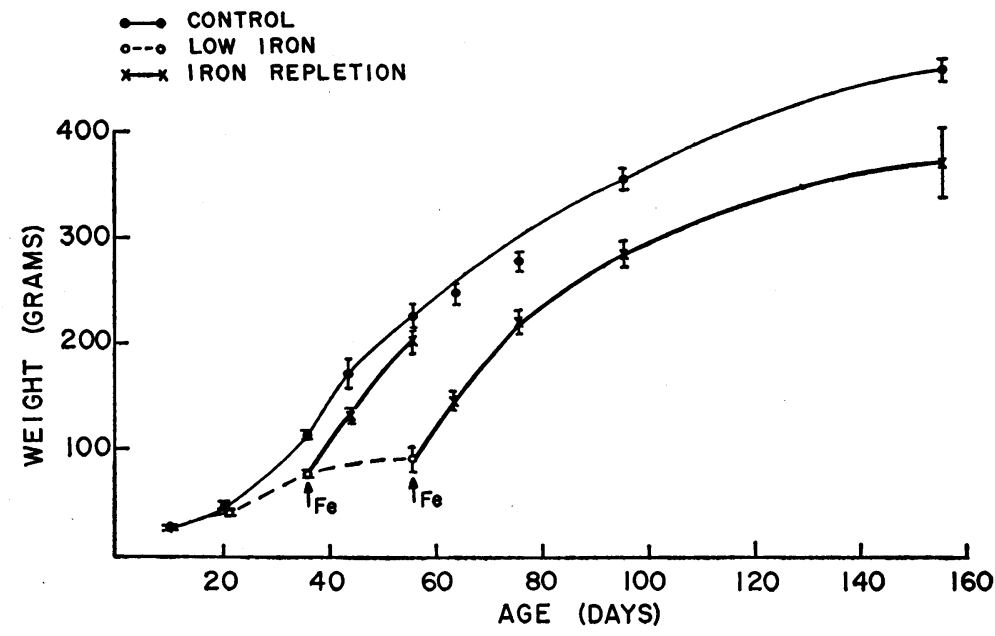

Fig. 1. Growth of rats DURING the DeVelopment and treatment of IRON DEFICIENCY. Arrows at 36 and 56 days indicate initiation of ferrous sulfate in each of two groups. Standard errors of the means are shown.

mals per group with these exceptions: In the case of 10- and 21-day-old animals samples of skeletal muscle and intestinal mucosa were obtained from pools of three to six rats each. In the 156-day-old group there were four control animals.

\section{Results}

Growth. The experimental diet was well tolerated. The rate of weight gain by animals receiving ferrous sulfate supplementation approximated that of rats on a normal diet of Purina laboratory chow. Animals on the low-iron regimen maintained their weight equal to that of the control animals until shortly after weaning at 21 days of age. Subsequently, the deficient group gained weight at a slower rate as illustrated in Figure 1. After

TABLE I

Response of hemoglobin and liver iron to iron repletion

\begin{tabular}{|c|c|c|c|c|c|}
\hline \multirow{2}{*}{$\underset{\text { (age) }}{\text { Group }}$} & \multirow{2}{*}{$\begin{array}{l}\text { Days } \\
\text { after } \\
\text { initia- } \\
\text { tion of } \\
\text { ferrous } \\
\text { sulfate }\end{array}$} & \multicolumn{2}{|c|}{ Hemoglobin } & \multicolumn{2}{|c|}{$\begin{array}{c}\text { Total hydrolyzable } \\
\text { liver iron }\end{array}$} \\
\hline & & Deficient & Control & Deficient & Control \\
\hline & & \multicolumn{2}{|c|}{$\mathrm{g} / 100 \mathrm{ml}$} & \multicolumn{2}{|c|}{$\mu g$} \\
\hline \multirow[t]{3}{*}{36 days } & $\mathbf{0}$ & $3.4 \pm 0.3 *$ & $12.0 \pm 0.8$ & $40 \pm 3$ & $460 \pm 60$ \\
\hline & 8 & $12.8 \pm 0.3$ & $12.5 \pm 0.2$ & $500 \pm 80$ & $640 \pm 30$ \\
\hline & 20 & $13.5 \pm 0.4$ & $14.2 \pm 0.4$ & $800 \pm 110$ & $760 \pm 70$ \\
\hline \multirow[t]{5}{*}{56 days } & $\mathbf{0}$ & $3.2 \pm 0.3$ & $15.1 \pm 0.5$ & & \\
\hline & 1 & $4.2 \pm 0.4$ & & & \\
\hline & 2 & $5.0 \pm 0.5$ & & & \\
\hline & 4 & $11.1 \pm 1.0$ & . & & \\
\hline & 8 & $15.0 \pm 0.3$ & $15.7 \pm 0.3$ & & \\
\hline
\end{tabular}

$*$ Mean \pm standard error of the mean. iron had been returned to the diet, a prompt increase in the rate of weight gain was observed. After initiation of oral ferrous sulfate, rats that had been deprived of iron for a 15-day postweaning period approached the weight of the control group in a shorter period of time than did animals that had been maintained on the deficient diet for 35 days. In the latter group of animals, after initiation of iron, an accelerated rate of weight increase was observed for about 20 days. Thereafter, however, their rate of weight gain decreased, and after 100 days of iron repletion, the originally deficient group still weighed less than the control animals; the $\mathrm{p}$ value obtained with the $t$ test for a weight difference between the two groups was $<0.1$.

Hemoglobin and liver iron. Animals exposed to the low-iron diet were anemic by 21 days of age. At this time the mean concentration of hemoglobin of the low-iron group was $5.2 \pm 0.30 \mathrm{~g}$ (standard error of mean) per $100 \mathrm{ml}$ compared to $9.8 \pm$ 0.30 in the control group. After weaning, this anemia became progressively more severe. At 36 days the mean concentration of hemoglobin had decreased to $3.4 \pm 0.3 \mathrm{~g}$ per $100 \mathrm{ml}$ and at 56 days of age to $3.2 \pm 0.3$. Corresponding control values were $12.0 \pm 0.8$ and $15.1 \pm 0.5 \mathrm{~g}$ per $100 \mathrm{ml}$ respectively. After initiation of oral ferrous sulfate at the same maintenance concentration as that provided the control group, concentrations of hemoglobin returned to control values within 8 days as shown in Table I. 
Iron stores in the liver provided an additional parameter of iron deficiency. Hydrolyzable liver iron values per total liver are indicated in Table I. At 36 days of age the total hydrolyzable liver iron was markedly reduced in the deficient group. In response to oral iron supplementation, iron stores in liver were rapidly restored. Within 8 days control values were approached, and after 20 days no significant difference between the two groups was observed.

Myoglobin. Skeletal muscle concentrations of myoglobin during the progression of iron deficiency anemia and its subsequent treatment are indicated on Figure 2. In the control animals, concentrations of myoglobin were in the same range as in animals of the same age on a diet of Purina laboratory chow, but these concentrations varied markedly with age. There was a rapid rise after 21 days with a peak at 76 days of age and a subsequent gradual decline. In rats on the low iron regimen, the mean concentration of myoglobin rose only slightly with age. At 36 days of age the mean concentration of skeletal muscle myoglobin in the low-iron group was $.19 \pm .03 \mathrm{mg}$ per $\mathrm{g}$ compared to the control value of $0.30 \pm 0.3$. After the iron-deficient animals had been placed on the iron supplemented regimen, an increase in myoglobin was observed, but control values were not approached until 20 days after initiation of therapy.
Animals that remained on the low-iron regimen until 56 days of age had a skeletal muscle concentration of myoglobin of $.28 \pm .03 \mathrm{mg}$ per $\mathrm{g}$ compared to the control value of $.56 \pm .02$. When iron was returned to the diet, these more severely and chronically iron-deficient rats did not approach control concentrations as rapidly as the 36-day-old animals. The control concentration of myoglobin was not reached until after 40 days of oral iron.

Cytochrome c. Concentrations of cytochrome $c$ in skeletal muscle and intestinal mucosa during iron depletion and repletion are shown in Figure 3. Although these tissues had a similar susceptibility to depletion of cytochrome c, they differed markedly in their response to treatment with iron. Muscle concentrations of cytochrome $c$ in the control animals rose rapidly between 10 and 21 days of age, then remained relatively constant until 76 days, and subsequently declined slightly. As in the case of myoglobin, concentrations of cytochrome $\mathrm{c}$ in the control group of animals did not differ significantly from those observed in rats on a Purina laboratory chow diet.

In the iron-deficient rats, a rapid decrease in cytochrome $c$ was observed before 36 days of age, but little change in concentration occurred thereafter. At 36 days of age the mean concentration of muscle cytochrome $\mathrm{c}$ in the group receiving low iron was $20 \pm 3.0 \mu \mathrm{g}$ per $\mathrm{g}$ compared to the con-

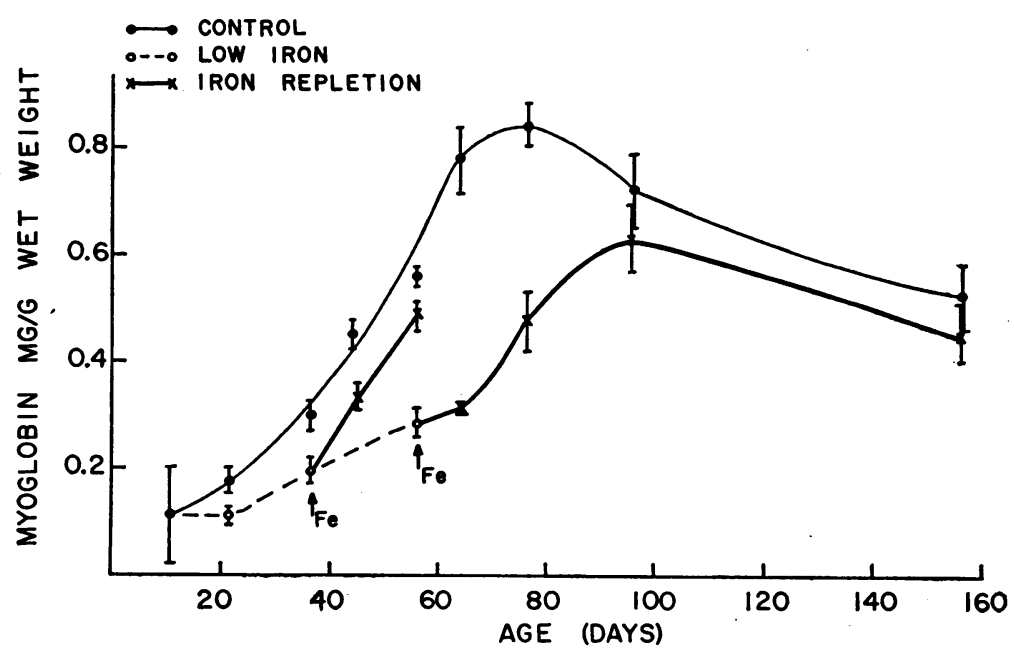

Fig. 2. Myoglobin concentrations in the RAT DURING DEVElopment AND TREATMENT OF IRON DEFICIENCY. Arrows at 36 and 56 days indicate initiation of ferrous sulfate in each of two groups. Standard errors of the means are shown. 


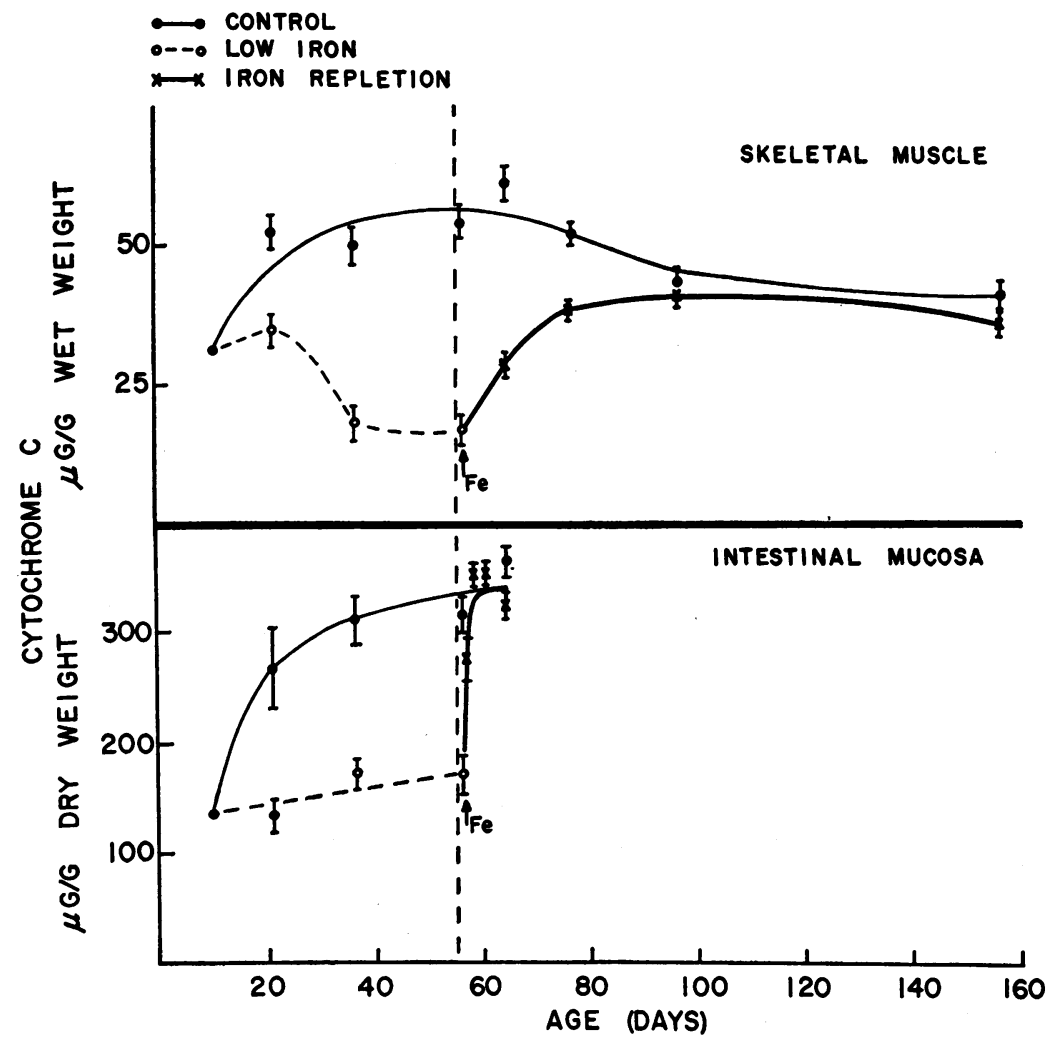

Fig. 3. Cytochrome c concentrations in the rat during the DEvelopment AND treatment of IRON Deficiency. Arrows at 56 days indicate initiation of ferrous sulfate. Standard errors of the means are shown.

trol value of $51 \pm 3.0$. When iron was returned to the diet at this time, the mean concentration of cytochrome $\mathrm{c}$ in the quadratus lumborum muscle reached control concentrations after 20 days.

In the rats maintained on the low-iron diet until 56 days of age, the mean concentration of cytochrome $\mathrm{c}$ was $17 \pm 4 \mu \mathrm{g}$ per $\mathrm{g}$ compared to the control of $54 \pm 3.0$. After initiation of oral iron, the figure for the repleted animals rose to $29 \pm 2 \mu \mathrm{g}$ per $\mathrm{g}$ after 8 days and $39 \pm 2$ after 20 days while the control concentrations remained relatively constant. Only after 40 days of iron repletion were control values attained. As in the case of skeletal muscle myoglobin, a longer period was required for attainment of control concentrations after the more prolonged period of deficiency. The peak concentration of myoglobin observed in the control animals during development was delayed and less prominent in this more chronically deficient group.

Cytochrome $\mathrm{c}$ in intestinal mucosa decreased rapidly in response to dietary iron deprivation. By 21 days of age severe deficiency had already been attained with $135 \pm 15 \mu \mathrm{g}$ cytochrome $\mathrm{c}$ per $\mathrm{g}$ dry weight in the deficient group compared to $270 \pm 39$ in the control animals. At 56 days of age the mean concentration of cytochrome $c$ was $171 \pm 15 \mu \mathrm{g}$ per $\mathrm{g}$ dry weight in the deficient and $362 \pm 18$ in the control rats. Upon initiation of dietary iron at 56 days of age, intestinal concentrations of cytochrome $\mathrm{c}$ increased rapidly. After 24 hours of oral ferrous sulfate, cytochrome $c$ in intestinal mucosa had increased to $276 \pm 20 \mu \mathrm{g}$ per g. After 48 hours, the concentrations had risen to the control range, where they remained at 4 and 8 days after initiation of iron repletion. Intramuscular administration of iron to the deficient rats resulted in a similar rapid restitution of intestinal mucosa cytochrome c.

The possibility that tissue heme protein depletion in the iron-deficient group might be related to inanition or low caloric intake was investigated. 
A group of eight rats was sufficiently restricted in its caloric intake to approximate the growth curve of the iron-deficient animals. Skeletal muscle and intestinal mucosa cytochrome $\mathrm{c}$ in these rats at 52 days of age were $50 \pm 4 \mu \mathrm{g}$ per $\mathrm{g}$ wet weight and $327 \pm 18 \mu \mathrm{g}$ per $\mathrm{g}$ dry weight, respectively. These concentrations did not differ significantly from values obtained in the rats fed the control diet.

Cytochrome oxidase. Specimens of upper jejunum were obtained from rats between 42 and 52 days of age. The histochemical localization of cytochrome oxidase in this tissue was similar to that described by Burstone (15). In four control animals the mucosal cells of the villi were the most intensely stained as shown in Figure 4. In four deficient rats a paler staining of the mucosal cells was observed as illustrated in Figure 5. Twelve iron-deficient rats were given intramuscular injections of $5 \mathrm{mg}$ of iron as Imferon and killed 8 to 48 hours later. After 12 hours an increase in cytochrome oxidase staining first appeared in the

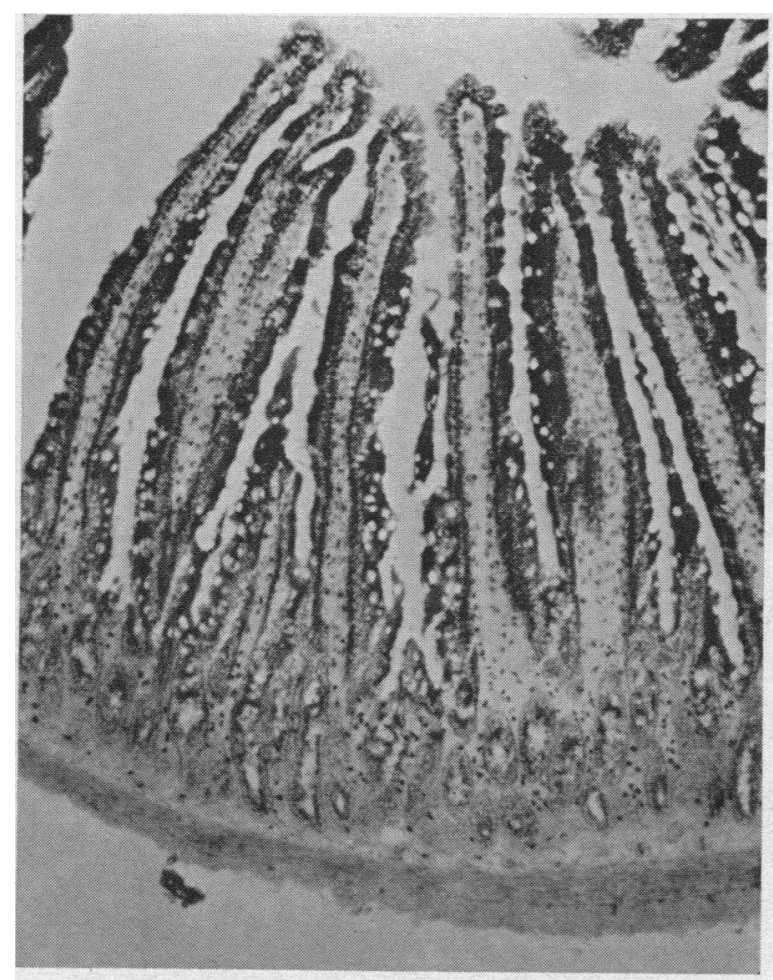

Fig. 4. Distribution of Cytochrome oxidase ACTIVITY IN THE JEJUNUM OF A RAT ON THE CONTROL DIET $(\times 100)$. The greatest activity is found in the mucosal cells of the villi.

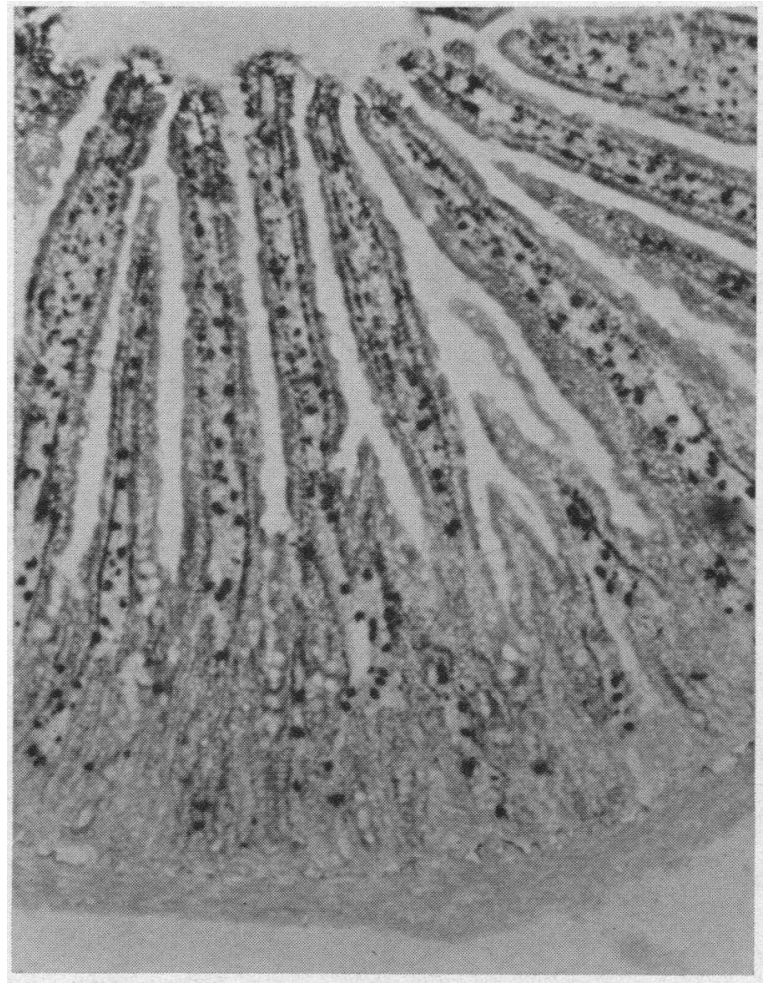

Fig. 5. Distribution of CYTOChrome oxidase ACtivITY IN THE JEJUNUM OF A RAT ON THE IRON-DEFICIENT DIET $(\times 100)$. The mucosal cells are stained less intensely than in the control animals.

mucosal cells at the bases of the villi. Between 18 and 24 hours the mucosal lining of the lower half of the villi resembled that of the control animals, and the tips of the villi retained the appearance of the deficient specimens as shown in Figure 6. Forty-eight hours after the injection of iron the staining pattern of the villi could not be distinguished from that of the control animals. The administration of $5 \mathrm{mg}$ ferrous sulfate by gastric tube resulted in a similar appearance of cytochrome oxidase activity at the bases of the villi after 18 hours as was observed in the animals injected intramuscularly.

\section{Discussion}

In the present study, the rapidity of repair of deficiency in cytochrome $c$ and myoglobin, in response to treatment of iron deficiency in the rat, varied according to tissue. Cytochrome $\mathrm{c}$ in intestinal mucosa had returned to control concentrations after only 2 days, although the animals remained severely anemic. In contrast, the time 


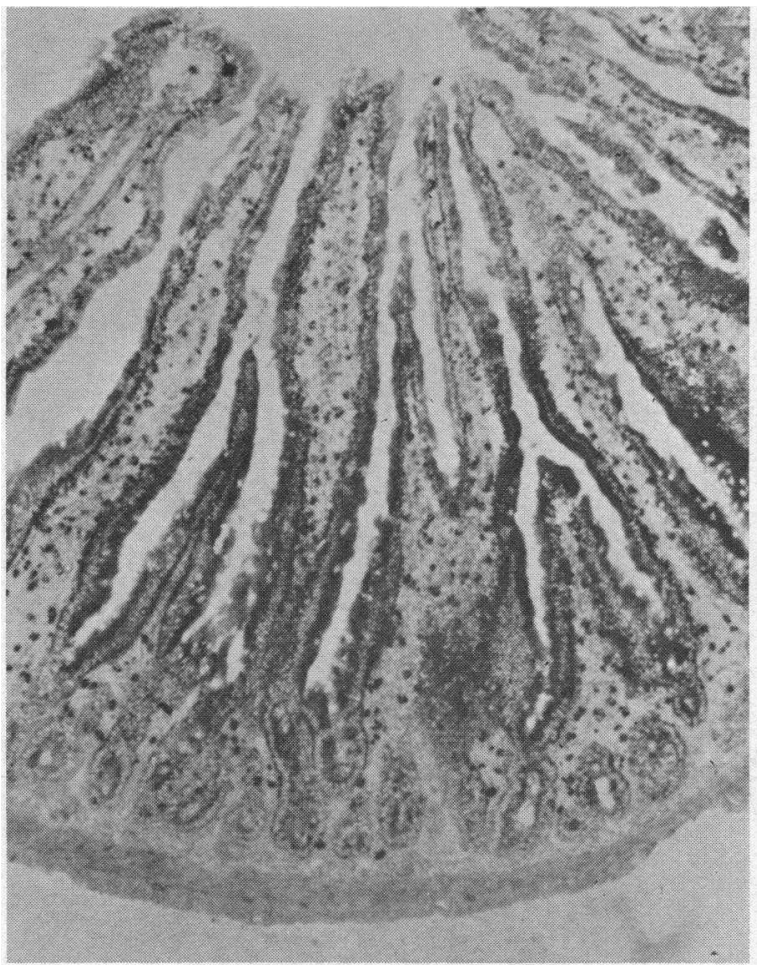

Fig. 6. Distribution of CYtochrome oxidase aCtivITY IN THE JEJUNUM OF A RAT ON THE IRON-DEFICIENT DIET 18 HOURS AFTER INTRAMUSCULAR IRON ADMINISTRATION $(\times 100)$. Note the fairly abrupt decrease in enzyme activity about halfway up the villi.

required for the repletion of cytochrome $c$ and myoglobin in skeletal muscle was five times longer than for the repair of the anemia. These divergent rates of heme protein repair appear to parallel variations in cell turnover in the normal rat $(17$, 18).

Messier and Leblond (18) used tritiated thymidine in their studies of cellular proliferation in the adult rat. They classified tissues into three types. Cells, such as neurons, that acquired no nuclear label were referred to as "static" cell populations. Tissues that had a low but persisting number of labeled nuclei were classified as "expanding" cell populations, and cells that had a high but rapidly declining number of labeled nuclei constituted "renewing" cell populations. Skeletal muscle is a slowly expanding tissue with little or no cell death and a low rate of new cell production. The mucosa of the small intestine, in contrast, is a renewal tissue that in the rat completely replaces itself in about 2 days. The replication of the mucosal cell takes place in the crypts. Subsequently the cells migrate towards the tips of the villi to be discharged into the intestinal lumen (18). In the present study, the repair of cytochrome oxidase deficiency appeared to proceed from the crypts, suggesting that the restitution of this enzyme activity is related to the production of new mucosal cells. A parallel relationship between the rate of cell renewal and the rate of heme protein repair has been suggested by previous studies. The rate of hemoglobin production with repair of nutritional anemias is dependent upon the production of new red cells. Ozsoylu and Diamond (8) found that red cell catalase and hemoglobin both return to normal at the same rate in patients treated with iron. Jacobs (6) has presented data suggesting that the activity of cytochrome oxidase in buccal mucosa, which has a rapid rate of cell renewal, may increase after only a day of iron therapy. Previous studies of Marsh and Drabkin (19) also suggest that cytochrome $\mathrm{c}$ turnover parallels the rate of cellular renewal in rat liver. These data suggest that tissue deficiencies in heme protein established during early growth in static or expanding cell populations may be only incompletely reversible by later repletion.

Widdowson and McCance (20) have emphasized the extent to which the duration of exposure to a deficient diet and the age of the animal determine the degree of recovery that is subsequently possible. After periods of caloric undernutrition, the repair of growth retardation was least complete in the youngest animals and in those on the limited diet for the longest duration. In the present study, rats maintained on the low-iron regimen for a brief period responded to iron repletion more promptly than did the chronically deficient group. Animals given iron after 36 days of age had approached the weight and muscle myoglobin and cytochrome $\mathrm{c}$ concentrations of the control group within 20 days. In contrast, rats whose iron was started at 56 days of age remained significantly deficient, according to these parameters, after 20 days.

Symptomatic improvement in response to iron treatment before there has been a significant rise in concentration of hemoglobin (21-23) suggests the possibility of an early repair of tissue heme protein deficiency (21). At present, however, no 
relationship between cellular heme protein content and any of these symptoms and signs of iron deficiency has been established. Beutler, Larsh, and Tanzi found no differences in consumption of oxygen with a constant exercise load in iron-deficient patients before and after therapy (24) and concluded that the symptoms of iron deficiency probably do not arise from a generalized defect in oxygen transport. Certain observations, however, suggest that depression of tissue heme protein is of physiological significance. In vitro studies utilizing mitochondrial suspensions have shown that even moderate losses of cytochrome $c$ reduce the rate of oxidative phosphorylation (25). A decrease in rate of respiration in homogenates of both muscle and liver from iron-deficient rats with succinate as substrate has also been observed (9, 26). The significance of these changes to the respiratory capacity of the intact animal remains to be determined.

\section{Summary}

The treatment of dietary iron deficiency in the rat resulted in rates of tissue cytochrome $\mathrm{c}$ and myoglobin repair that differed markedly from the rate of increase in concentration of hemoglobin. After initiation of oral supplementation, cytochrome $\mathrm{c}$ in intestinal mucosa returned to control concentrations within 2 days compared to the 8 days required for the correction of anemia. Cytochrome $\mathrm{c}$ and myoglobin deficiencies in skeletal muscle persisted even after hemoglobin concentrations had returned to normal. Normal concentrations were not observed until 40 days after initiation of oral ferrous sulfate. These divergent rates of repair of heme protein parallel known rates of cell renewal within these tissues in the normal rat.

The repair of cytochrome oxidase deficiency in the intestinal mucosa appeared to proceed from the crypts and extended about halfway toward the tips of the villi within 24 hours of either oral or intramuscular iron administration. These findings suggest that the restitution of cytochrome oxidase activity is limited by the production of new mucosal cells.

Iron repletion after a 15-day period of iron deprivation resulted in a more rapid correction of skeletal muscle myoglobin and cytochrome c deficiencies than was observed after a 35-day period of this diet.

\section{Acknowledgments}

We would like to thank Mrs. Helen Geoffrion and Miss Yolanda Leonard for their skillful technical assistance.

\section{References}

1. Hahn, P. F., and G. H. Whipple. Iron metabolism. II. Its absorption, storage and utilization in experimental anemia. Amer. J. med. Sci. 1936, 191, 24.

2. Cohen, E., and C. A. Elvehjem. The relation of iron and copper to the cytochrome and oxidase content of animal tissues. J. biol. Chem. 1934, 107, 97.

3. Gubler, C. J., G. E. Cartwright, and M. M. Wintrobe. Studies on copper metabolism. XX. Enzyme activities and iron metabolism in copper and iron deficiencies. J. biol. Chem. 1957, 224, 533.

4. Beutler, E. Iron enzymes in iron deficiency. I. Cytochrome C. Amer. J. med. Sci. 1957, 234, 517.

5. Beutler, E. Iron enzymes in iron deficiency. IV. Cytochrome oxidase in rat kidney and heart. Acta haemat. (Basel) 1959, 21, 371.

6. Jacobs, A. Iron-containing enzymes in the buccal epithelium. Lancet 1961, 2, 1331.

7. Salmon, H. A. The cytochrome $c$ content of the heart, kidney, liver and skeletal muscle of irondeficient rats. J. Physiol. (Lond.) 1962, 164, 17.

8. Ozsoylu, S., and L. K. Diamond. Decreased activity of an iron-containing enzyme (catalase) in iron deficiency (abstract). Society for Pediatric Research, Thirty-third Annual Meeting, May 1963, p. 73.

9. Dallman, P. R., and H. C. Schwartz. Distribution of cytochrome $\mathrm{c}$ and myoglobin in rats with dietary iron deficiency. Pediatrics 1965, 35, 677.

10. McCall, M. G., G. E. Newman, J. R. P. O’Brien, L. S. Valberg, and L. J. Witts. Studies in iron metabolism: I. The experimental production of iron deficiency in the growing rat. Brit. J. Nutr. 1962, 16, 297.

11. Biörck, G. On myoglobin and its occurrence in man. Acta med. scand. 1949 (suppl. 226).

12. Crosby, W. H., J. I. Munn, and F. W. Furth. Standardizing a method for clinical hemoglobinometry. U. S. armed Forces med. J. 1954, 5, 693.

13. Åkeson, A., G.v Ehrenstein, G. Hevesy, and H. Theorell. Lifespan of myoglobin. Arch. Biochem. 1960, 91, 310.

14. Rosenthal, O., and D. L. Drabkin. Spectrophotometric studies: XI. The direct micro spectrophotometric determination of cytochrome c. J. biol. Chem. 1943, 149, 437.

15. Burstone, M. S. Modifications of histochemical techniques for the demonstration of cytochrome oxidase. J. Histochem. Cytochem. 1961, 9, 59.

16. Kaldor, I. Studies on intermediary iron metabolism : V. The measurement of non-hæmoglobin tissue iron. Austr. J. exp. Biol. med. Sci. 1954, 32, 795.

17. Bertalanffy, F. D., and C. Lau. Cell renewal. Int. Rev. Cytol. 1962, 13, 357. 
18. Messier, B., and C. P. Leblond. Cell proliferation and migration as revealed by radioautography after injection of thymidine- $\mathrm{H}^{3}$ into male rats and mice. Amer. J. Anat. 1960, 106, 247.

19. Marsh, J. B., and D. L. Drabkin. The biosynthesis of cytochrome $c$ in vivo and in vitro. J. biol. Chem. 1957, 224, 909.

20. Widdowson, E. M., and R. A. McCance. The effect of finite periods of undernutrition at different ages on the composition and subsequent development of the rat. Proc. roy. Soc. B 1963, 158, 329.

21. Harris, J. W. The Red Cell. Cambridge, Harvard University Press, 1963, p. 63.

22. Wintrobe, M. M. Clinical Hematology, 5th ed. Philadelphia, Lea \& Febiger, 1961, p. 731.
23. Beutler, E., V. F. Fairbanks, and J. L. Fahey. Clinical Disorders of Iron Metabolism. New York, Grune \& Stratton, 1963, p. 83.

24. Beutler, E., S. Larsh, and F. Tanzi. Iron enzymes in iron deficiency: VII. Oxygen consumption measurements in iron-deficient subjects. Amer. J. med. Sci. 1960, 239, 759.

25. Jacobs, E. E., and D. R. Sanadi. The reversible removal of cytochrome $c$ from mitochondria. J. biol. Chem. 1960, 235, 531.

26. Mackiewicz, M., L. Kasprzak, L. Obuchowicz, and J. Michejda. Activity of succinic oxidase enzyme system in experimental anemia. Acta physiol. pol. 1961, 12, 255. (Abstract in Blood 1961, 18, 618.) 